Pragmatics 8:1.47-78.

International Pragmatics Association.

DOI: 10.1075/prag.8.1.04hen

\title{
NARRATIVE STYLES OF PALESTINIAN BEDOUIN ADULTS AND CHILDREN
}

\author{
Roni Henkin
}

This paper contrasts natural oral narratives of Bedouin adults and children (ages 8-11) in the Negev Desert (South Israel). The analysis showed some striking stylistic differences, on both developmental and genre-related grounds. Adults, narrating tribal legends in a stylized, performed idiom, used distinct styles for the textual levels of orientation, plotline, and direct speech; the children told folktales and anecdotes in a relatively undifferentiated, near-conversational style. Adults set out from a concrete, non-past stage and shifted to a past plotline; whereas the children's folkloristic openings, in the distant past, drifted to a concrete, relived present. There were significant differences in rhetorical means for perspectivizing, information packaging, connectivity, and tempo control. The children's narrative style was found to be much "flatter" and less evaluative than the adults', in keeping with developmental findings. However, some of the older children displayed global text organization, using diverse cohesive means typical of the folktale. This may show these children to be more sensitive to global genre structure than to local rhetorical means.

\section{Introduction}

Oral narratives of adults and children are known to differ across languages, cultures, and genres. Developmental studies of children's narrative have largely been based on elicited personal narratives or picture book stories. The present paper focuses on the yet unexplored styles of spontaneously narrated traditional stories in Palestinian Bedouin Arabic.

In the Bedouin culture oral narration is a highly valued, highly stylized form of art. Men, women, and children tend to narrate different genres in distinctive styles. Men traditionally narrate tribal history in a distinct poetic-narrative idiom; these lengthy chronicles pivot round memorized epic verses, introduced by improvized, but still highly formulaic, explanatory narrative (Palva, 1992; Muhawi \& Kanaana, 1988). As time elapses and history transforms to legend, deeds assume superhuman dimensions and mingle with the supernatural (Sowayan, 1992). These legends, however, remain distinct in realm, content, and style from the folktales and fantasy associated with women and children. The difference in attitude to supernatural in the two genres is reflected, for example, in the source attributed to it: magic in the children's folktales typically lies in a magic wand or torch, whereas in the legends we may find God's messengers, turned to snakes, able to reverse castration through the invocation 'In the name of God'. The tribal 
legends, set in the nomadic lifestyle of pasturing and raiding, pivot around desert law and traditional manly Bedouin values such as bravery, horsemanship, tribal loyalty, blood vengeance, generosity, and women's honour (Sowayan, 1992; Rosenhouse, 1984). The "women's and children's stuff"-- folktales, jokes, and anecdotes, on the other hand, usually have no specific Bedouin content, and are as likely to be set in palaces or bazaars as woods and villages. Moreover, many of the women in the Negev tribes today arrived through marriage; hence many of the stories transmitted to the children actually originate outside the Negev.

The present corpus, adopted from Henkin (1985), reflects the genre/ demographic split: the adult material comprises six fairly lengthy men's legends, recorded by $\mathrm{Y}$. Katz, and marked by the narrators' tribal initials as $\mathrm{R}$ (for $\mathrm{A} b u$ $R a b \bar{i}$ ' $a$ ) and $A$ (for 'Azāzme); the much shorter children's texts are from my own recordings of the Jarabi' family in the Negev hills. In the evenings all the encampment children would gather round the kerosene lamp to "tell stories to the recorder", with no prior specification of the genre I was interested in. From the long stream of folktales, anecdotes, jokes, and songs, amid constant competition for the floor, I chose 12 texts, narrated by JSk(13), JZa (13), JA (12), JZ (11), JS (11), and JAd (8).

Three distinct layers of the narrative text will be discussed in turn to see how the adults and children differ in each, in both developmental and genre-related issues:

(i) orientation, concentrated mainly in the stage-setting opening;

(ii) plotline or narrative skeleton;

(iii) direct speech or mimetic mode. 1

\section{Orientation}

\subsection{In the opening}

Bedouin narratives typically open with a pre-plot stage-setting. Table 1 contrasts typical openings of Negev adults and children.

\section{NOTES}

* I am grateful to Chaya Bar Itzhak, Ruth Berman, and Dan Slobin for reading the paper and providing helpful comments; also to Ibrahim Muhawi and Muhammad Siddik for information on Palestinian dialects. None are responsible for any shortcomings of this paper.

1 A fourth level is left for future treatment. This is asides-- external evaluation (Labov, 1972), i.e., parenthetical explanations and expressivecommunicative interpolations). In terms of narrating persona (Fleischman, 1990) we can relate these four levels respectively to: (i) an artist painting the scene; (ii) a historian recounting retrospectively; (iii) an actor performing; (iv) an educator explaining, commenting, evaluating. 
TABLE 1: NARRATIVE OPENINGS TYPICAL OF NEGEV ADULTS AND CHILDREN

\begin{tabular}{|c|c|c|c|c|c|}
\hline DEMONSTR. & EXISTENTIA & $\mathrm{PAST}^{2}$ & DISTANCER & SUBJECT & TEXT \& GLOSS \\
\hline $\begin{array}{l}\text { hāda } \\
\text { 'this' }\end{array}$ & $\begin{array}{l}\mathrm{fi} \\
\text { 'there is' }\end{array}$ & $\varnothing$ & $\varnothing$ & $\begin{array}{l}\text { wähad šix } \\
\text { 'a sheikh' }\end{array}$ & $\begin{array}{l}\text { ADULT R1 } \\
\text { 'There was a sheikh' }\end{array}$ \\
\hline & $\begin{array}{l}\text { fi } \\
\text { 'there is' }\end{array}$ & $\begin{array}{l}\text { kān } \\
\text { PAST }\end{array}$ & $\begin{array}{l}\text { marrah } \\
\text { 'once' }\end{array}$ & Juha & $\begin{array}{l}\text { CHILD JS } 11 \\
\text { 'There was once Juha' }\end{array}$ \\
\hline
\end{tabular}

Three features differentiate the openings in the table, and throughout the texts: ${ }^{3}$

a) all but one of the adult texts, but none of the children's, opened with the near demonstrative häda 'this'; this disjunctive deictic points out the characters introduced in the Bedouin legend openings, and beyond, much as actors are introduced onto the stage in the theatre ${ }^{4}$

b) adults invariably used atemporal nominal clauses, which depicted a concrete, non-past setting; the children, on the other hand, anchored their openings in the distant past, often overmarking pastness with a recurrence of the past marker $k \bar{a} n \cdot{ }^{5}$

c) the lexical past marker and distancer marrah 'once (upon a time)' occurred in 10 out of the 12 children's texts, but in none of the adults'.

These three differentials add up to one: the adult style is concrete 'here and now', the children's is distant and past. Significantly, one of the two children who opened in non-past adult style immediately back-tracked to insert the temporally distancing elements kān and marrah. She then repeated these repair formulations several times:

2 Throughout the paper, I use temporal and aspectual terminology, e.g., (non-)past, (im)perfective, for the conceptual notions. The actual verbal and participial forms, which basically oppose completion (Henkin, 1985), are denoted by formal symbols, such as F, Y, P (2.1).

3 The common feature is an existence proposition, which is typical of 3rd person narratives crosslinguistically ('There was', il $y$ avair, žyl byl, etc.).

Children, though rarely adults, sometimes predicate the existence of a determined entity, in this case the personal name Juha (cp. Henkin, 1994a).

4 Similarly, Blau (1960) shows that Palestinian narratives typically open with a disjunctive nominal phrase, e.g., 'A farmer. He had a son...'

5 Non-contingent $k \bar{a} n$ is infrequent in the Negev-Sinai dialects (Henkin, 1993) and in other Bedouin dialects of this region (Rosenhouse, 1984). As expected, kān did not occur in any of the adult openings, but it did open all but one of the children's texts. 


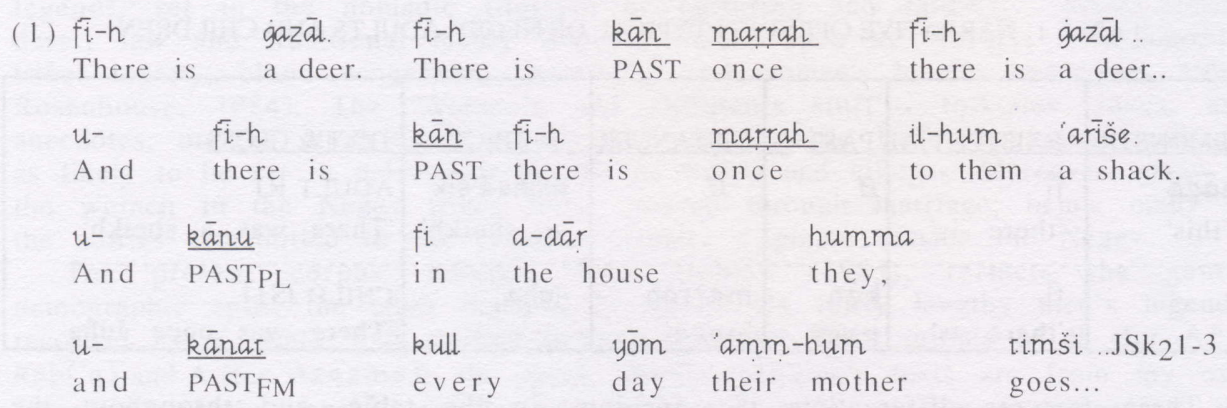

'There is a deer. There is... once there was a deer (with three little ones). And there is...once they had a shack. And they would be in the house, and their mother would go each day..'

As we see in (1), past markers may heap up in some of the children's openings. Adult settings, on the other hand, maintained their initial concreteness throughout the introduction in nominal or non-past imperfective predications:

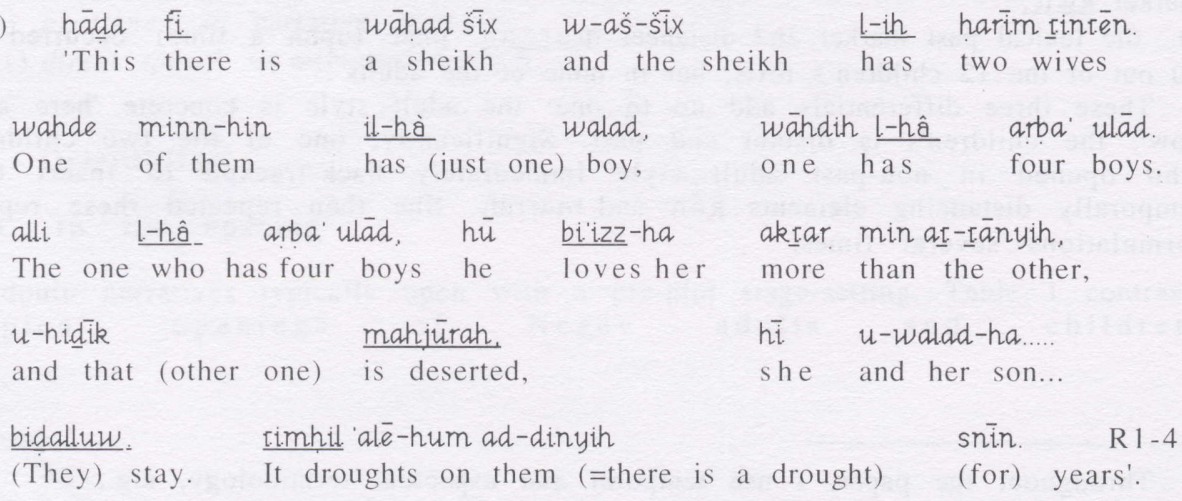

These three differentials, $h \bar{a} \underline{d} a, k \bar{a} n$, and mart $a h$ are, in part at least, genreconditioned: the Bedouin legends are conceived of as real historic events with an actual, ever-relevant significance; the conception of actuality leads to concretizing the narrative setting by demonstratives and non-past or atemporal, generic settings (Henkin, 1996); the children's folktales, on the contrary, are typically set in the distant past of fantasy, characterized crosslinguistically by opening formulas such as 'Once upon a time in a distant land there was.....' Such spatio-temporal distancing widens the horizons of imagination in preparation for a tall tale, and removes any commitment to reality (Fleischman, 1989b). Indeed, the openings of Palestinian folktales, and those of neighbouring dialects, are characteristically keyed with distancing formulas, often in rhymed prose (Henkin, 1996). The oral folktale as a genre thus seems to be, at least partially, the model for the Negev children's openings.

More generally, children's use of past tenses in fictional settings may be linked to the crosslinguistic tendency to associate past with fantasy and irrealis. 
Evidence of this tendency in another genre may be the imparfait préludique of spontaneous children's playacting (Warnant, 1966; Henkin, 1992).

Moreover, the same distancing elements are also characteristic of written literary fiction; and since children often choose to narrate tales which they read, or have read to them, at school from a written, literary medium, such elements may be seen as literary influence on the children's storytelling. The literary register may be intentional if storytelling is conceived of as a literary activity fit for the style of written literature. ${ }^{6}$ Note, however, that in literary Arabic, as in the folktale openings, one past marker is generally sufficient for an entire section of non-past predications. So the repetitive temporal marking in (1) is not a replica of any adult style, but rather a distinct children's style, with the overmarking tendency known in general for that age group.

Another mixed genre-developmental factor to be considered is the analytic tendency of the dialectal conversational register in general, and of children's language in particular. While adult Negev narrative consistently has non-past imperfective forms in the orientation, for depicting past habitual or progressive events, children use analytic, non-ambiguous past markers.

In sum, whether we choose to attribute the children's overmarking of the past to genre, literary influence, cognitive or developmental factors, or to a combination of these, one thing is clear--the adults and the children occupy opposite poles of a Concrete-Distant style scale, as far as the opening goes.

\subsection{Beyond the opening}

Once out of the highly formulaic openings, however, the temporal setting seems to undergo opposing drifts: adult orientation had occasional past markers; so, in relation to the consistent non-past opening, the subsequent adult orientation can be seen as moving to the right along the Concrete--->Distant scale. The children's orientation, however, was invariably non-past, in contrast with the overmarked past opening. The children's orientation could thus be seen as undergoing a Distant --> Concrete drift. This "opposing drift" may reflect the narrators" concept of their respective genres (adults conceive of the events as reality; children as fiction) merging, as the narration proceeds, with the actual process of narrativizing (adults recount; children relive). We shall see this same "opposing drift" in the narrative layer.

\section{Summary: the orientation layer}

The adult legends start like plays from an atemporal, concrete, actualized stage-setting, while the children locate their folktales analytically in the distant, literary, folkloristic past of fiction. Subsequent adult orientation drifts somewhat to past, children's to a consistent non-past. This opposing

6 Berman \& Slobin (1994) and Berman (1996) discuss formulaic story book openings used by 9 -year-olds crosslinguistically. Such literarizing, especially if associated with memorized texts, is to be expected at openings, which tend to be both better retained in memory and more carefully formulated than other sections. Literarizing is not, however, limited to openings: my daughter, at the age of 5, when retelling TV children's stories to her brother (4) who had missed them, used many literary or high Hebrew constructions such as na'aley ha-yalda 'the girl's shoes', sa'ar-a ha-arox 'her long hair' throughout. 
drift may reflect the opposing concepts of reality vs. fiction, merging with the narrativizing processes of recounting vs. reliving.

\section{Plotline}

The typical adult chronicle-legend plotline is a loosely structured, open collection of episodes, creatively woven together with each telling in winding, often non-chronological ordering (Sowayan, 1992). This structure seems typical of performed oral narrative, including genres such as Medieval epics (Fleischman, 1989a, 1990).

The children's folktales, on the other hand, are short and tightly structured, often in cyclic patterning; their anecdotes are still shorter and more compact.

This section contrasts several techniques of adults and children for texturizing their narrative by perspectivizing, packaging, connectivity, text segmenting, and tempo control. Most of the techniques discussed below serve more than one of these narrative functions.

\subsection{Tense switching}

In narrative, tenses may assume narrative-specific functions in addition to their referential temporal-aspectual denotations. Tense switching often serves pragmatic functions. These include internal evaluation on the expressive level, and both perspectivizing (or grounding) and text segmenting on the textual level (Fleischman, 1990). This is especially true of oral narrative traditions, where literary strategies such as subordination for backgrounding are not favoured (Fleischman, 1989a).

The Negev Arabic verbal system is minimal: the indicative finite verb paradigms are just two, the complete (perfective) past fa'âl (abbreviated $F$ ) and the incomplete (imperfective) non-past (b)yafial (abbreviated Y). Adult narrative exploits these, supplemented by the imperative (abbreviated I) and the participle (abbreviated P), in an intensive system of oppositions.

The default narrative tense is typically F; it depicts bounded, completed, consecutive events on the plotline--which is not to be mixed up with foreground, a matter of perspective (Chvany, 1984). Off the plotline, orientation tends to be atemporal or non-past (1.2): nominal and participial predications render states, while Y renders events, whether simultaneous, iterative, or generic.

The marked forms, on and off the plotline, more or less reverse this pattern. The default off-plotline forms are marked when on the plotline, and vice versa, with some difference in the marked functions:

TABLE 2: NARRATIVE TENSE USAGE (ADULTS)

\begin{tabular}{|l|l|c|}
\hline & DEFAULT & MARKED \\
\hline ON PLOTLINE & $\mathrm{F}, \mathrm{Y}, \mathrm{P}$, imperative \\
\hline OFF PLOTLINE & $\mathrm{Y}, \mathrm{P}$, nominal pred. & $\mathrm{F}$ \\
\hline
\end{tabular}

What do the marked forms mark? Off the plotline, F-forms mark anteriority, with no special perspectivizing value. On the plotline, however, the non-default forms primarily mark perspective and text boundaries: a plot-forwarding $Y$ can function as a highlighting narrative present (2.1.1), while $Y$ in presentative syntagms, along with $P$ and nominal forms, serves for static visualized concretizing (2.1.2). These and the narrative imperative (2.1.3) are evaluative 
foregrounders, "zooming" the events to a visualized, concrete here and now, and switching from a distant, detached narrator's perspective to an involved, subjective participant's. This systematic perspectivizing of mature adult style contrasts sharply with the children's use, as we shall now see for each form.

\subsubsection{Narrative present}

The actional narrative present is not as pervasive in the Negev as in some other Bedouin styles, where it has been considered a simple variant of the past (e.g., Gensler, 1976). In the Negev adult style the narrative present is still a marked evaluative means, for foregrounding, concretizing, and contrasting in a performative presentation. Moreover, this perspectivizing function combines with a text-segmenting function of the narrative present, of signalling initial episode boundaries (cp. Herring, 1991, for Tamil). Many episode starts are highlighted by one or two Y's, after which the narrator returns to F-form:

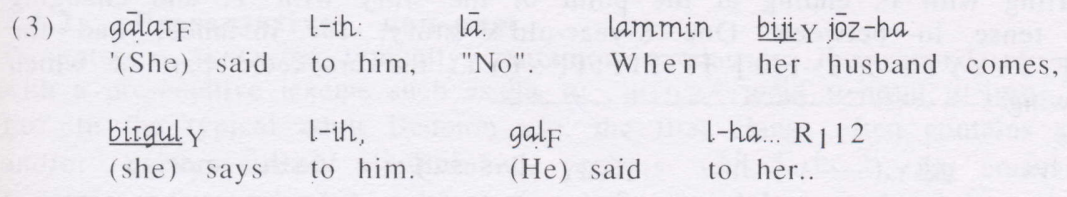

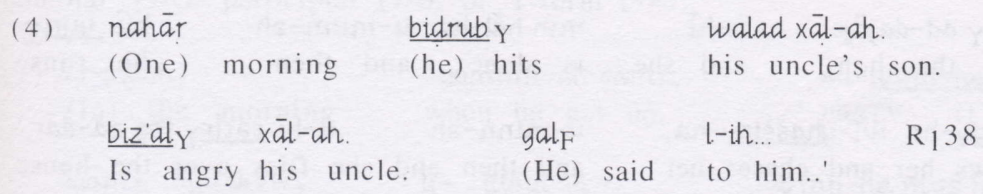

Children used the narrative present much more often and less discriminately. The younger ones, in particular, tended to switch to it fairly early on in the story, abandoning the detached, orderly retrospection of the adult default plotline for the more concretely visualized plotline in present.

Some older children, however, used the switch to narrative present in adult fashion, for foregrounding and highlighting textual boundaries (cp. Berman, 1996). The following ends a 13-year-old's narrative, in consistent F-form, about a scruffy little girl who tried to play with some animal playmates Each refused because she was dirty, until finally one advised her to go and clean herself up. The last two lines, in narrative present (italicized), highlight the solution and moral of the story:

(5) u- hi tgōtary u-txalli $i_{Y} a m m-h a$ 'And she goes and has her mother

u-rgassy adäfir-ha. u-hi tiiY

and cut her nails.

$$
u \text {-igotaruY }
$$$$
9
$$

ala l-banāt w- al-biss

to the girls and the cat tnaddif $Y^{-}$ha $u$ - thammim $Y^{-h a}$ clean her and bathe her 'a-l-așfür u-hi taliaby ma'-āh to the bird and she plays with it

\section{wo- yil'abuY JZa7-}

and (they) play'

Some children switched over just once from a monolithic past to a monolithic present at some stage in the narration. Some such switches seemed to be textually motivated, as above, while others, usually nearer the beginning, seemed 
arbitrary. In the anecdote $\mathrm{JS}_{5}$ ' the entire plotline was in Y-form. ${ }^{7}$ It seems as if the tendency to visualize and formulate everything as here and now grows as children plunge into the events, with excitement increasing on the one hand, and adult literary influence decreasing on the other. Again a Distant--> Concrete drift seems to characterize the children's style, contrasting with the Concrete--> Distant adult drift in the transition from opening to plot.

In the more mature style of bi-directional switching, the older children differed from the younger ones in the size and function of the switched segments. The more mature narrators would insert short segments of the shifted tense at actional peaks, e.g., FFFFFFFF-Y-FFFFF-Y-FFF-Y-FFFFFFFF-Y-FFFFF-Y-FFF (JZ3-20). (8) below shows a part of this sequence where the narrative present, in combination with a presentative pattern (2.1.2), serves a double function of perspectivizing and text segmentation in marking climatic, recurring key events. Younger children, on the other hand, tended to switch large chunks, typically starting with $\mathrm{F}$, ending at the point of the story with $\mathrm{Y}$, and changing the leading tense in between. One 8-year-old's story, for instance, had the pattern FF--[YYYYYYY--F-Y--FFF] FFFFFFFFF--YYY, the bracketed part of which is the following:

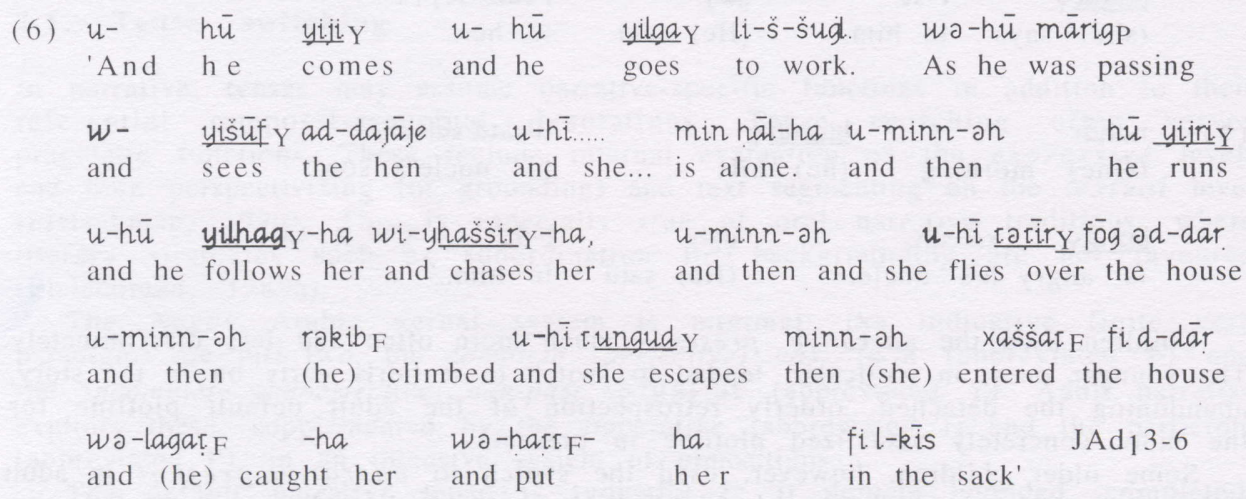

The children's narrative present also differed structurally from the adults', as (5) and (6) above clearly show-- the children's syntagms are predominantly syndetic (co-ordinated) SV structures with an explicit subject pronoun, e.g., $u-h u^{-}$ yimsi 'and he goes'. This is distinct by several features from the adults' typically asyndetic (conjunctionless), so-called "subjectless" or V(S) clauses of (3-4) above, e.g., yimši 'goes'. (more on subject specification and syndesis in 2.2 and 2.6.2).

An additional text-segmenting function of adult tense switching, apart from the episode boundary marking seen above, is metatextual: Y sequences identify a segment as orientation, predominantly as an opening, while $F$ sequences identify the plot segments (complication, resolution). This tense partition highlights the dual nature of the legend: in setting (orientation) and relevance (evaluation) the legend is non-situated and generic, i.e., non-past; but as a series of historical events, it is construed as a single, complete past time narrative. We are given to visualize a historic past plotline drawn in an everactual, concrete background and foreground. 
The children's primary tense switch was in the opposite direction. The children start by emphasizing the fictionality of the fantasy they intend to tell, but in the actual telling they are drawn into the time and actuality of the story, possibly through the loss of literary influence. 8 This gradual shift was interpreted here as a Distant (Fictional)-->Concrete drift, rather than a clear textual marker, as in the adult case. We have seen, however, evidence of textual organization in the older children's switching patterns, with the narrative present used to link recurring, pivotal episodes; likewise Y served for the solution, moral, and ending of a story--possibly even as a conversational, turntaking cue, signalling that the narrator is done, and willing to give up the floor.

The children's narrative present, in sum, was used more, and generally more arbitrarily and less flexibly, than the adults' narrative present. Some of the older children, however, made mature perspectivizing and text-cohesive use of the F-Y switch.

\subsubsection{Presentative non-past}

Presentative syntagms typically contain two clauses, the second of which opens with a presentative lexeme such as illa $w$-, winn-, wala, $u$-hay $y, \underline{w}$-linn 'voilà', 'and Lo!' In the typical adult Bedouin use, the first clause often contains subordination and/or backgrounded simultaneous events $(71,4,6,7)$, for contrast with the following foregrounded presentation of the unexpected sight, in visualized nominal ( $7 \underline{2})$, participial $(7 \underline{5})$, or Y-form $(7 \underline{8})$ :

(7) as-subih

'(In) the morning

3 gām ${ }_{F} \underline{4}_{\text {yifakkiry }}$

(He) began to look 1yöminn-ah gāmp,

when he got up,

li- $\underline{\text { dulūl-ih, }}$

for his camel, 2u-winn-ha rabi

PRSTV. it's grass.

${ }^{5} w$ inn-ha muš mawjūdih.

PRSTV.it's not (to be) found.

Grili. F: al ha-l-äli $\underline{I}_{\text {yfakkiry, }}$
(He) climbed on this hill to look,

$\underline{8}_{\text {winn }}$ yišü $f_{Y}$..

R 16-21

PRSTV. (he) sees..'.

This pattern combines several rhetorical effects: (a) an abrupt stop of the rapid flow of narrative F-forms, often of dynamic motion verbs $\left(\frac{1,3,6)}{3,}\right.$ and perception verbs $\left(\frac{4,7}{2}\right)$; (b) abrupt zooming to a static "slide show" visualizing of foregrounded, concretized non-past forms $(\underline{2}, \underline{5,8})$; (c) a switch in perspective from the narrator, in the first clause, to the protagonist and his perception, in the second--a mature cognitive and narrative skill; (d) an accumulation of tension around peaks.

Lexical foregrounders, such as 'suddenly', do not occur in our texts, so it is not surprising that the presentative is very frequent --(7) above, for instance, is followed by three almost consecutive presentatives, to a total of 28 (!) in that one text.

Some of the older children's texts, such as JSk 1 and JZ, showed this adult use of presentatives for foregrounding and peak marking. Moreover, presentatives

8 An exception to the opposing drift tendency was the use of demonstratives: throughout the narrative text the children used mainly the distant demonstratives hada $\bar{k}(a)$, hadīk(e), haduläk, as in (37), whereas adults preferred the near demonstratives hăda, he di hadöl, ha-. In this respect, then, the adult style remained consistently more concrete throughout. 
served these older narrators in the textually cohesive refrains so typical of folktales, especially when introducing magic transformations: (8) demonstrates a presentative pattern repeated in four successive refrains, (reproduced in (20) below), where an old man waves his magic wand to create (and then destroy) assets for three brothers:

$$
\begin{aligned}
& \text { u-hü yhazzy bakūr-ah... } \frac{\text { winn-ah }}{\text { yarla'y }} \text { mayy JZ26 } \\
& \text { 'And he waves his wand }
\end{aligned}
$$

However, more typical of the younger children was a colloquial version of the presentative, preceded by the evaluative, somewhat emphatic gèr 'only': 9

(9) gălF: …ūli l-birmìl illi tahât.

'(He) said, "..Pull outFM the bottom barrel."

ale $-h$

baramil u-himār.

barrels and a donkey...PRSTV.(=So then)

has on it

al-barmil

5

the barrel and the donkey PRSTV. (=so of course) he is fallen'

\section{gè winn il-birmil illi that}

PRSTV.(But of course) the

bottom barrel

sahabat $\mathrm{F}$

(she) pulled out

$$
\text { tăintP JS } 13-
$$

This intensified variant of the presentative seems to present as inevitable the outcome of negatively evaluated actions. But the judgemental force did not always seem to be intended--rather it seemed like a generalized over-use of the syntagm. The visualizing, presentative syntagms of (7-8) represent the perspectivizing mature use, typical of the adults and older children.

\subsubsection{Narrative imperative}

The narrative imperative is a particularly expressive foregrounding, performative device of colloquial Arabic narrative. In the following glosses, it is marked by a capitalized imperative and an exclamation mark:

$$
\begin{array}{lll}
\text { yömen ja' } & \text { nisib-ah } & \text { usgut I } \\
\text { When (he) cal-bir } \\
\text { Fall! } & \text { into the well, }
\end{array}
$$

$\begin{array}{ll}u-h \bar{u} & \frac{\text { etla' I }}{\text { G-igra' } I} \text { rās } \\ \text { and he } & \text { Go out! and Cut off! the head of your brother in law }\end{array}$

u-xud I il-alagär.. u-gōter $w$-istig I al-xazānah.

A 41-43

and Take! the documents and Go! and Rob! the treasury

'When he (the hero) came (with his brother in law), his brother-in-law fell into the well (that had been prepared to trap the hero), and he went out and cut off his brother-in-law's head and took his documents (so he would not be recognized) and went and robbed the treasury'

The striking performative effect of this form is partly due to the shifts in mood and deictic centre: the narrator assumes a "stage-director" role, issuing 
"stage directions" to the actors. This 2nd person addressing, of course, personalizes the narration.

Significantly, while the narrative imperative has all but replaced $\mathrm{F}$ as leading narrative form in some adult texts, there is not a single case of it in the children's texts. Both genre-related and developmental issues may account for this absence. Firstly, the narrative imperative is characteristic of the Bedouin poetic genre (Palva, 1977), and is much less frequent in other styles, such as Palestinian folktales (Henkin, 1994b).

A developmental barrier for its use may be the rather complex grammar of deictic switching; moreover, this device involves the narrator personally in a highly performative, modal stance, as the narrative evolves to a play, and objective narration to subjective evaluation. The children may not have yet acquired the flexibility to switch from narration to performance by such sophisticated means, though they do, of course, use the imperative in its referential command-request use.

\subsubsection{Verbal compounds}

Typical of Palestinian narrative are motion verb auxiliaries in a narrative tense, followed by a non-past content verb, also usually by a motion verb. Such complexes combine sudden instantiation and consequent foregrounded continuation. Most typical in Bedouin legends is the auxiliary $j \bar{a}(-k)$ 'came (to you)' followed by a motion P:
(11)

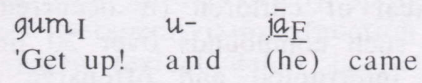
$-k$
to you
näfidp
mäš̀tp
R 144

Referentially, this syntagm means 'he got up and walked off'. Its stylistic evaluative force comes from combining the dynamic lexical content of four motion verbs, the indexicality of 'come', the plotline narrativity of the auxiliary's tense, and the foregrounded, visualized participles. The personalized, listeneroriented deictic 'to you' adds concreteness and performed foregrounding. The total effect is extremely dynamic, on the one hand, and highly concretized, on the other. This combination seems particularly well suited to depicting the dynamic lifestyle of riding and raiding, in which these legends are set.

Not surprisingly, children did not use these motion compounds: firstly, as just said, these auxiliaries are rather genre-specific, typical of the oral Bedouin narrative (Palva, 1991), while other dialectal narrative traditions and genres have others. 10 Like other stylistic characteristics of the adult legends, this feature too was absent from the children's style. Which is not to say the children abstained from using compounds. They made intensive use of the auxiliaries of ordinary conversational register, such as șār 'became' and dall 'remained', whose primary referential function is to denote inception and continuation respectively of an iterative event or state. These evidently have additional textual functions, differing somewhat for adults and children: many adult texts showed a global textual funcion of the inceptive compound, for episode instantiation and foreshadowing (Bamberg \& Marchman, 1994); this function occurred only once in a child's text, significantly in the most mature narrative of the corpus: 'And he waves the wand and all is honey. And he started selling, selling every day, and he began to earn a lot ....'. JZ13. Typical of the children's style was the local use of

10 For instance, Palestinian narratives (including Galilean Bedouin) are full of the auxiliary $q \bar{a} m$ 'rose', which in some texts is the basic narrative form; Moroccan children's personal narratives show abundant use of ja (u)F] (Caubet, 1995); each of these syntagms occurred just once in our corpus. 
the inceptive 'began to', exemplified in. (12 2 ), i.e., 'began to shout' (on one particular occasion).

As for dall 'continue', it was used to denote not only continuation or reinstantiation (12 $\underline{3}$ ) of an event, as expected, but often also its beginning (12 1 and 22 below), which may seem totally counter-intuitive. It has a subjective, evaluative (often negative) stance, such as of depicting the action as either extremely abrupt and crude or counter to expectation, while focusing on its continuation:
rakban $\mathrm{F}$
al-hamir
'(They) mounted
the donkeys
u- $\underline{1}_{\text {dallon }} \mathrm{F}$
māšyātp
and continued
walking (=went off)

an-

'ugbo šwayya

away from her...

After a little (while)

märagp 'ale-ha

zalama

$u-\underline{2} \underline{\text { sarat }} \underline{\underline{F}}$

and (she) started

irnädi $a \bar{e}-h$.

calling him
gäl.
gälat F ....
$u^{-3}$
dall $_{\mathrm{F}}-\mathrm{ah}$
māšip
JA $12-16$
(He) said,... (She) said,...
And he continued
walking (=went off $)^{\prime}$

This evaluative use of dall-compounds is typical of children (it occurred only once in the adult texts). JA, for example, had 10 such compounds over 20 lines of text, with a resulting impression of perpetually interrupted and offensive action contrary to normal expectations.

\section{Summary: tense switching}

Adults switch perspective from a basic F-form plotline of past narrated events to foregrounded, concretized narrative present (also a boundary marker), narrative imperative, presentatives, and motion compounds. Some older children use narrative present and presentatives textually for recurring episode binding. In general, however, children switch less forms (discarding specific Bedouin narrative uses), more mechanically, with the present tending to take over in a drift of fictional to relived.

\subsection{Word order and subject specification}

In the conversational register of this dialect the unmarked order of the main sentence constituents is subject-verb (SV). 11 In adult narrative, however, word order differentiates sequences on and off the plotline, again with marked perspectivizing values for the non-default orders. The default plotline sequence is $\mathrm{V}(\mathrm{S})$, as in (131-3), where the implicit subject is morphologically marked in the

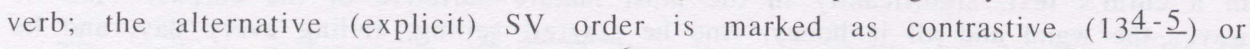
topicalized, often in cleft-structure (13흐). In the following, numbers preceding

11 Except existential/possessive structures and indetermined subjects (Bauer, 1926). I use the conventional notation of $\mathrm{V}$ to include nominal predicates. 
verbs indicate an SV pair, whether an explicit $S$ or an implicit, morphologically encoded subject:
(13) $\frac{1}{f} \bar{a} t$
alèe-ha. $\quad \underline{2}$ gälat.
3̧aăl...
as -subh
4ैâl-'arabs šälat

'(He) came to her. (She) said,..(He) said,...(In) the morning the tribes moved

c a m p

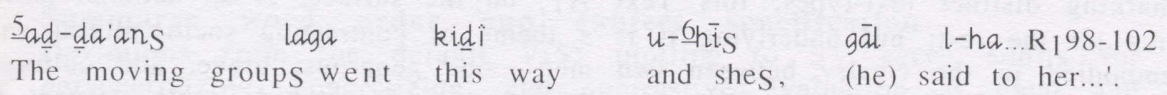

Off the plotline, this scheme is reversed, with SV as default. $\left(13 \frac{5-6)}{\text { can be }}\right.$ interpreted off the plotline, as simultaneous events included in the general "moving camp" of (13느); on the other hand, they could be taken as forwarding the plot, in which case VS would have been more natural and the present order markedly contrastive. Left dislocation (13흐) is always topicalized, whether interpreted as on or off the plotline.

Presentatives are predominantly ordered SV, and are often predicated nominally. They occupy an intermediate position regarding the plotline: they seem to forward the plot, but by "leaps" rather than linearly along an orderly plotline. They present a static, resulting "slide show" view, rather than the dynamic progression of plotline events, which are left to inference. Thus they may be seen as not strictly speaking on the plotline, hence the SV order.

This porspectivizing furrtion of word order is not surprising, considering how scarce lexical detail is in this style (2.3). Lexical markers of orientation, iterativity ('over and over') and simultaneity '(mean)while', simply do not occur in our texts; these off-plotline notions are encoded syntactically in SV order, primarily in nominal, relative, and circumstantial clauses, 12 but often just by virtue of SV order (13늘.

An additional effect of the SV order is of 'nominalizing' the structure, 13 by relegating the verb to secondary position, and placing more emphasis on the actors than the plot. In impressionistic terms, SV order may be felt to be somewhat more static, concrete, and descriptive than the dynamic VS. The order reversal also adds rhythmic variation, as the normal $V(S)$ pattern can get monotonous when used too intensively.

As the categories of person, number, and gender are incorporated in the verb, explicit subject pronouns are grammatically redundant; and while the conversational register "drops" subject pronouns, Arabic adult narrative style only adds them when pragmatically motivated: 14 topicalization, contrast, subject

\footnotetext{
$12 \mathrm{SV}$ is obligatory in circumstantial clauses, and pragmatically unmarked in iterative and nominal clauses. VS, for example, may focalize a preposed predicate: șigir... ôl-walad häda R84 '(he was) small....that boy' (rightdislocation structure). SV is also obligatory in some syntagms like ma $(w \bar{a})$ had 'no one', and characterizes some genre-specific formulas, such as $h \bar{u}$ big $\bar{u}$. 'he says' for introducing Bedouin verse (Palva, 1992).
}

1.3 In traditional Arabic grammar, SV sentences are considered nominal rather than verbal. 
change, etc., usually go with subject specification, 15 often supplemented by intonation and word order variation. Typical is right dislocation of a topicalized subject, eg. ja' 'min gazu hū $A_{1} 13$ lit. 'came from raiding he'; this may be combined with adverbial preposing wi-'a-l-mayyah ga'ad $h \bar{u} \quad \mathrm{~A}_{1} 40$ 'and on the water (well) sat he'. Both these examples, significantly, are from a text which shows how word order and subject specification can also be significant on a metatextual level, marking distinct text-types: this Text $\mathrm{A}_{1}$, on the surface, is an actional narrative like all the rest; but underlying it is a theme of contrasting socio-cultural values, embodied in the rivalry between two men-- one generous, brave, and cultured, a true Bedouin, the other mean, cowardly, lazy, and stupid-- with respect to a woman who has to choose between them. The characters, their feats, and the values so contrasted, are set in contrastive word order, rather than the ordinary narrative order; the text is marked syntactically as a contrastive-descriptive one, even in the absence of lexical contrastives.

Considering the analytic-linear tendencies found so far in the children's style, we expect to find more explicit subjects in SV order on the children's plotlines than on the adults', with no necessary marking for perspective. And indeed this is the case: the children's plotlines very frequently proceed in pragmatically unmarked SV sequences:

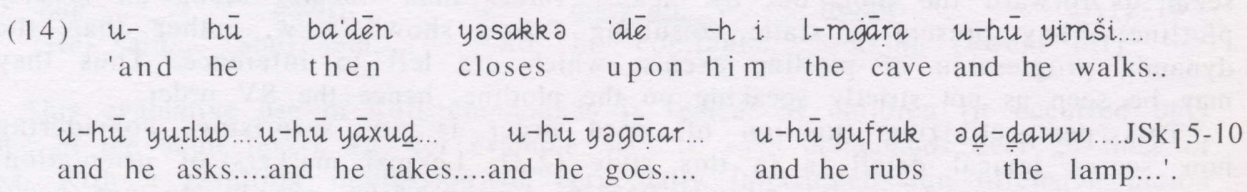

See also (5-6) above and (24) below. A count over one text showed the ratio V : VS : SV to be $3: 1: 4$ in JSk 116 as against $37: 5: 1$ in adult $\mathrm{R}_{5}$. This shows $\mathrm{SV}$ to be the most popular in children's style, and clearly the least popular in adult style. Adults, as we have said, predominantly use subjectless verbs, and specified subjects follow their verbs; children tend to begin with the subject.

This generalized subject specification is in keeping with developmental findings that children have to develop prodrop as part of the communicative skill to assess the listener's informational needs (Berman \& Slobin, 1994). The denser $\mathrm{V}$-alternant, which packages the verbs more tightly to a single unit, is not infrequent in children's narration; but it tends to occur randomly-- the child

elision, subjectless, etc.; however, I will continue to use both terminological sets for convenience.

15 Although subject change does not actually warrant subject specification: rawwah ysayyeh 'a-amm-ah u-götar b-al-wazztēn w-at-tayr A12 '(heA) went off crying to his mother and (heB) went off with the two geese and the bird'; the same is true of the children's texts: $u-h u$ hazz...u-șar $i b \bar{i}$ '...... ja ' $a-\underline{-}-\underline{t} \bar{n} \mathbf{n} i$, găl...JZ13 'and he(A) waved his wand and (heB) started to sell....(He $\left.\mathrm{He}_{\mathrm{A}}\right)$ came to the second, $\left(\mathrm{HeC}_{\mathrm{C}}\right)$ said..... Since syndesis and asyndesis also interchange freely across subject change, the listener has to stay extremely alert to succeed in participant tracking.

16 Excluding obligatory constructions, such as explicit subject in circumstantial clauses. 
seems to roll into this faster construction as his narrating takes on a fast pace (2.7), possibly for external reasons like siblings' impatience.

Moreover, children did not use either adverbial preposing or postposed pronominal subject at all; these more sophisticated word order strategies apparently come later, as narrativizing skills mature.

\begin{abstract}
Summary: word order and subject specification
Deviations from the default $V(S)$ plotline to SV serve adults for perspectivizing, concretizing, and contrastive evaluation at local and metatextual levels. Children have largely standardized the linearanalytic, explicit SV of the conversational register, with no marked perspectivizing value.
\end{abstract}

\title{
2.3. Elaborative detail
}

Both the legends and the folktales are known to their audiences. This shared knowledge allows for non-chronological ordering and, especially, much ellipsis, with circumstances, surroundings, causality, motivation, and emotions inferred from the actions and speech. Little use is made of lexical and syntactic evaluators (Labov, 1972), such as intensifiers and comparators. Attributes are few, often formulaic, e.g., ha-l-bint alli hēk Allah bixlig 'a girl such as God creates' (=a very pretty girl). Verbs are extremely simple, with little lexical content packaged in them: neutral gâl 'said', for instance, serves in contexts where English narrative might have 'whisper', 'ask', 'repeat', 'answer', 'confide', 'announce'..... Imagine, for instance, the illocutionary verbs an English narrative may use in depicting a mother, tipped by her son into a boiling water tub--'shriek', 'beg', 'implore', 'scream'? These do exist in the dialect, but the present text has gälat: hutr-ni! hutıni! R 147 'she said, "Put me (down)! Put me (down)!"'

The one semantic sphere which displays lexical richness is motion. Not surprisingly, motion verbs were especially abundant in the dynamic, dramatic legends depicting the typically nomadic activities of riding and raiding. The adults used 47 different motion verbs, often specialized for direction, manner, and purpose, e.g., wirid 'take the beasts down to a water source to drink' or $h \bar{a} \bar{s}^{\prime}$ 'round up the enemy's camels as loot'. The children also used many different motion verbs, but their 26 types were more general, and characteristic of the conversational register. So, the standard literary 'going'-verb rāh typical of adult narrative, did not occur at all in the children's corpus, while the conversational equivalent aggad, so common in the children's texts, occurred only once in the adult corpus, out of 200 motion verb tokens.

\subsection{Verbal chain structure}

In the actional adult narratives, especially in the case of motion verbs, bare verbs are predominant. Verbs tend to cluster in trios, typical of Arabic narration in general (Muhawi \& Kanaana, 1988):

(15) jaww,

'(They) came, xastuw,

lost,

\section{raj'uW. R168}

returned'.

However, chain length varies for tempo control, with longer chains slowing down the pace and shorter ones speeding it up (2.7). A particularly frequent lone verb, interspersed with the trios for a particularly staccato effect, is the subjectless, unmodified (i)ja 'came': 
(16) i.jô.

lamminn i.jâ,

fakkar,

$x \bar{a} f$.

ri.ji

R66

'(He) came. When (he) came, (he)looked, took fright, returned'

In the children's narratives, on the other hand, verbs are typically postmodified by accusative or dative objects, locative prepositional phrases, etc. Chain boundaries are vague:

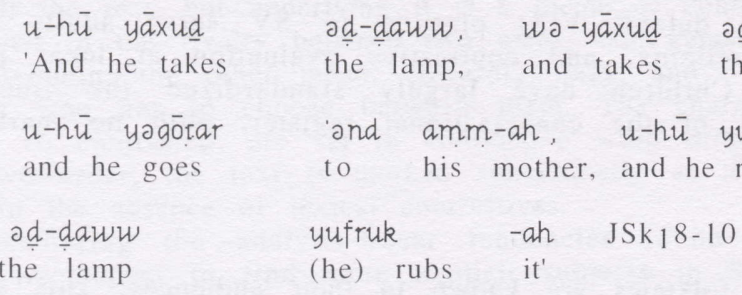

This vagueness of the chain boundaries is partly due to the lexical material surrounding the verbs as subject specification and modification, and partly to syndesis (2.6.2) and repetition.

\subsection{Repetition}

Both the adults' and the children's narratives contain numerous repetitions, but these are typically of different kinds. Adults make intensive stylistic use of local repetitions, a well-known strategy of oral narrative for internal evaluation by intensification and suspension of events (Labov, 1972), specifically at actional and thematic textual peaks (Fleischman, 1989a). Besides the textual function of marking peaks, and the pragmatic functions of "diluting" information flow and gaining time, these are rich in local euphonic and rhetorical effects, such as alliteration and rhyme (Henkin, 1996). Palestinian narratives of all genres are rich in morphological, syntactic, and lexical repetition, often in binomials and other collocated formulas, e.g., b-al-kull $w$-al-kililin R534 'with all and all',u-'abd-ih $u$-häl-ih $u$-māl-ih $\mathrm{R}_{1} 86$ 'and his slave(s) and situation and property'. But the Negev legend seems particularly fond of event repetition. The following is a favoured repetitive pattern of speech segments "echoed" in the narrative, and cp fn. 26 for similar echoing within dialogue:

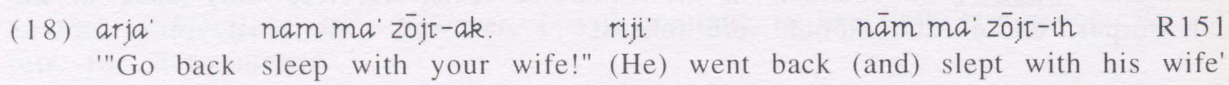

(19) shows repetition of the extremely frequent verb jiá'came', in a verbal trio $(\underline{1-3})$, and in a special echoic pattern known as backstitching $(\underline{3-4})$ (Fleischman, 1989a): 17
(19) $\frac{1}{\frac{1}{\mathrm{a}} \overline{\mathrm{H}}}$
māši.
(He) came walking. Came
$\underline{\underline{j} a}$
ala xwān-ah
$\underline{3}_{\text {i.ja. }}$.
to his brothers...
came.

17 Other terms include reprise or (more generally) overlay style, and time-line subordinate clauses (Fleischman, 1989a, 1990); also sentence recycling (Holes, 1995). 


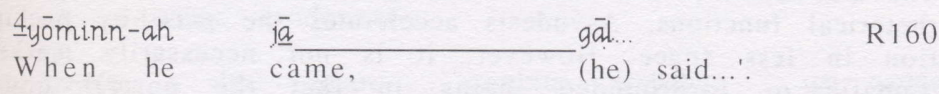

This pattern of repeating a clause-final verb in a following "when"-clause has been recognized as typical of Bedouin oral poetic narrative (Palva, 1992). It has also been documented in geographically distant dialects (cf. Holes, 1995), but is rare in other genres, such as the geographically close Palestinian folktales (Henkin, 1996). As a possibly genre-related phenomenon, then, it may be expected to be absent in the children's style. And indeed it was.

The children's local repetitions involved mainly grammatical suffixes, repeated in a mechanical manner (5-6), or unstructured backtracking for repair and time gaining (23). 18 In the children's corpus I found no cases of the "speechechoing" technique of (18), and only rare cases of backstitching.

The older children's folktales, however, showed clear patterns of structured textual repetition of formulaic key phrases at recurring episode peaks. This kind of repetition is characteristic of the folktale as described by Lüthi (1982); both the cyclic-episodal structure and the highly formulaic language produce repetition. The richest example for this in the corpus is the consistent marking of the episodal peaks of magic in the tale of an 11-year-old:

(20) $u$-hū hazz al-bakūr winn-ha.

JZ12 'And he waved the wand and Lo!.'.

wo-yhazz al-bakür winn.

JZ15 'And (he) waves the wand and Lo!'.

$u-h \bar{u}$ yahazz bakūr-ah. winn-ahJZ26 'And he waves his wand and Lo!..'.

u-hü yahazz al-bakür winn-ah. JZ28 'And he waves the wand and Lo!.'.

For textual repetition of speech in the older children's tales, see 3.1. In sum, the packaging of repetition mainly as a local-rhetorical means by adults, and as a global-textual connective by the children, is a genre-related differential of these two styles.

\subsection{Connectivity}

\subsubsection{Parataxis vs. hypotaxis}

Parataxis, or juxtaposition, is a known characteristic of oral narrative in general, performed stories in particular (Wolfson, 1982). Hypotaxis or subordination, outside speech, was rare in all our texts, as expected, except for the backstitching pattern just discussed (2.5). The children's corpus, however, had far less hypotaxis even than the adults': the adult: child ratio for relative clauses, for example, was $36: 7$; 'when'-clauses (excluding backstitching) numbered $17: 1$. This was not surprising, in view of the general tendency in children's language for more parataxis than adult language.

\subsubsection{Syndesis vs. asyndesis}

Clause co-ordination can be syndetic (lexically bound), most neutrally by the conjunction 'and,' or asyndetic (conjunctionless, zero-bound). The 'and'/zero options are generally seen as syntactically free variants in Palestinian narrative

18 The entire children's corpus contained only two cases of repetition for intensity, distribution, iterativity, etc., which in Arabic, as a language with no grammatical Aktionsarten and little use of intensifiers, are typically rendered through repetition. 
(Blau, 1960). The alternation in our adult texts, however, is not arbitrary, but has stylistic and rhetorical functions. Asyndesis accelerates the pace by packing in more information in less space. However, it is not necessarily marked as particularly dramatic or forgrounded, being in fact the normal unmarked plotline sequence pattern. It is syndesis that is marked for smooth, legatto progression within one functional unit, packaging the events into a single bundle in decelerated tempo. Syndesis is naturally more prevalent off the plotline, in orientation, simultaneity, and contrasting. 19 On the plotline, chains of syndetic, modified verbs are effective in depicting characters indirectly, by listing their actions:

(21) misâk-ah

'(He) caught him

$\underline{u-j a \bar{b} b-a h}$

u-jabbar-ah

u-laff ala rijl-ih $\quad \underline{u-\ldots} \quad \underline{u-h a r t-a h ~ f-a l-b e r ~ r a b a-a h}$

and bound his leg and... and put him in his house

$\underline{u-g a ̈ l . . . . R} \mathrm{R}_{14-5}$

and said,...

(21) portrays a man's good deed in bringing home a wounded stranger and caring for him. Although it is a plotline sequence, the slow, listing configuration of consistent syndesis and morphological repetitions has the effect of accumulating these good deeds for the purpose of portraying a character. Although no lexical or other marker of duration is supplied, we sense long lasting or atemporal virtue. This depiction sets the stage for a particularly sharp contrast in the stranger's consequent ungrateful behaviour, presented in short, asyndetic clauses of a fast, dramatic configuration.

So chunks of syndesis contrast rhetorically with chunks of asyndesis. Switching within a chain is also an effective rhetorical means of the adult style. Marked asyndesis, in the midst of a syndetic sequence, may detach a verb from its surroundings in staccato fashion, packaging it as an individual unit that attracts independent attention. Thus the transition from opening to plot in all the adult narratives is asyndetic, as are most other boundary markers.

In other cases, syndesis and asyndesis are balanced in couplets for rhythmic parallelism (along with reversed F/I sequences):

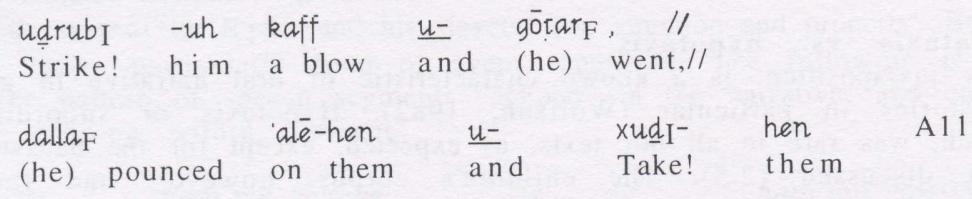

'He struck him and went off, pounced on them and took them'

The children's style, in contrast, was predominantly syndetic throughout, including the transition from opening to plot. This major boundary was invariably marked off asyndetically in the adults' texts, but $66 \%$ of the children's opening to plot transitions were syndetic. A typical case is (23). It follows a syndetic opening 'There is a pretty girl, and there are other girls, and the pretty

19 Although contrast can be conveyed asyndetically too, syndesis makes for explicit contrast. A good example of both syndetic and asyndetic contrastives is (2) above: 'One of them has just one boy, one has four boys (asyndetic implicit contrast).... The one who has four boys, he loves her more than the other, and (= whereas) that other one is deserted.' 
girl's name is $\mathrm{H}$, and the other girls are not as pretty as her' JAl-2. This plot then starts, and continues, syndetically:

(23) wa-'axadan tha gâlan ....... 'axadan âl-bäbūr wa-'axadan 'âr-rhi. 'and (they) took her (they) said....(They) took the oven and took the grindmill wa- 'axadan 'âr-rhi
and took the grindmill and took adan od-dike

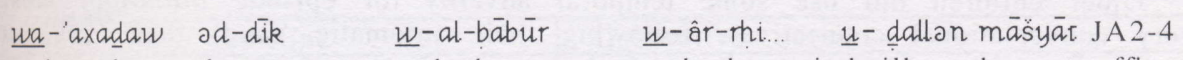
and took the rooster and the oven and the grindmill and went off'

Two more random countings show the predominance of syndesis in children's style: (i) an 8-year-old's story contained only five asyndetic verbs, out of 34(!); of these five, 3 occurred in the opening, in backtracking repair-work, and one in a final fixed formula; (ii) overall in the children's corpus, speech was introduced syndetically in over $14 \%$ of the cases, while the adult corpus contained only 3 syndetic saying verbs out of 324 , i.e., under $1 \%$.

\subsubsection{Lexical connectives}

Adults used varied temporal adverbs, e.g., nahär 'in the morning' or 'one morning', as-subh 'in the morning', al-migrib 'in the evening', $m$ a'a l-lèl 'that night', 'ugb middih/al-gadà/sanah aw sanatēn 'a little later', 'after lunch', 'a year or two later'. These serve both referentially for temporal setting, and textually for marking boundaries, such as the transition from opening to plot (Berman, 1996). On the other hand, as we see in (24), the children predominantly connected both clauses and episodes with 'and' $(\underline{1,2,3}$ and more 1 , 'then' $(\underline{7)}$, or 'and then' $(\underline{5,11})$. (24) begins a plot, after an opening where Juha tells us of his intention to go and sell his ten donkeys at the market:

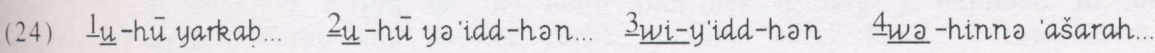
And he rides... and he counts them.... and counts them, and they are ten.

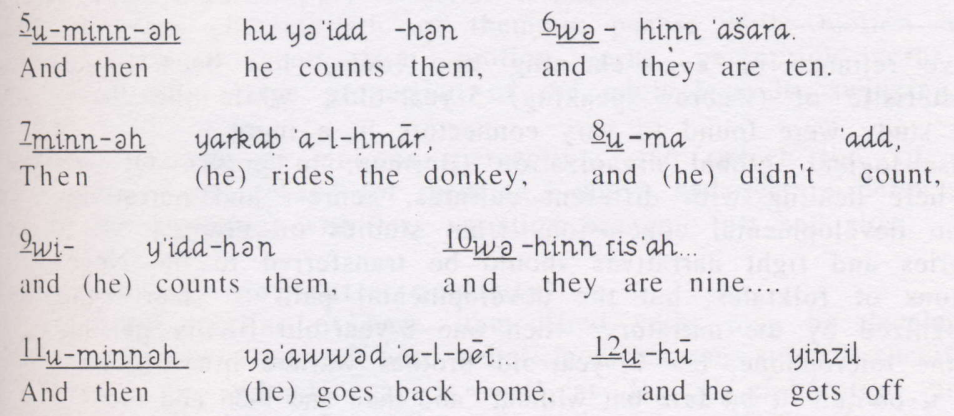




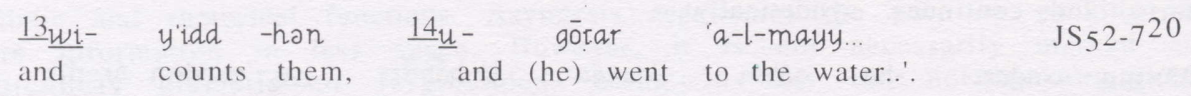

Moreover, children often piled up these connectives in non-grammatical constructions, such as $u$-ba'dèn $\underline{u-h} \bar{u}$ yarla' 'and then and he goes out', and see (6) above 'and then and she flies over the house'. 21

Older children did use some temporal adverbs for episode initiation, mostly very conversational connectives, following their automatic '(and) then', e.g., $u$ ba'dèn £äni marra... JA16 'and then another time..., or ba'dēn $f$-al-äxor.... JS 22 'then finally... The one case, in the entire children's corpus, of a temporal adverb in the transition from opening to plot was the very formulaic yo-m $\mathrm{mn}$ il-'iyyām JSk 24 'one day', lit. 'a day from among the days'. The children's use of lexical connectives was, in general, much flatter than the adults'.

\subsection{Tempo control}

In the absence of lexical pace markers, such as 'quickly', 'soon', 'gradually', the distinct rhythms of the adults' and children's styles are established by a variety of non-lexical accelerators and decelerators. Many of these have already been presented in other functions; now it is time to assemble them as pace markers that control information flow and rhythm. This section breaks down the concept of tempo into distinct elements, which combine differently in adults' and children's styles into fast and slow configurations. Table 3 shows some elements associated with tempo variation (cp. Fleischman, 1990, sect. 6.8), classified into elements of form, content (type and quantity), and syntax:

20 Such extensive reliance on event-chaining 'and (then)' has been found especially characteristic of (Hebrew-speaking) 5-year-olds, while the 9year-olds of that study were found to vary connectors in a more hierarchical, causal-logical, global organization (Berman, in press). Of course, we are here dealing with different cultures, genres, and narrative traditions, and no developmental conclusions from studies on elicited Hebrew frog stories and fight narratives should be transferred to the Negev children's narrations of folktales; but the developmental path is clearly the same, as is recognized by the narrators: when one 8-year-old finally got his chance to take the microphone, his 17 -year-old brother warned him bass bidūn u-ba'dēn u-ba'dèn u-ba'dèn 'but without "and then and then and then.'"

21 Children's pretextual use of 'and then' for local utterance connecting (Berman \& Slobin, 1994; Berman, in press), i.e., to signal that more speech is coming, occurred in some of these children's texts outside the corpus. A fine example of this use in an Egyptian dialect is the following, by a 12-year-old narrator: kān fí 'arāžil, amir . wu-ba'dān mirāt-ih 'amīra. wu-ba'dāyn kān and-ih birt.. There was a man, a prince...and then his wife was Amira. And then, he had a daughter...' (Behnstedt \& Woidich, 1988: 362, 1-2). 
TABLE 3: LINGUISTIC MEANS FOR TEMPO ALTERNATION

\begin{tabular}{|c|c|c|}
\hline & FAST & SLOW \\
\hline $\mathrm{i}$. & perfectivity & imperfectivity \\
\hline ii. & motion & speech and perception \\
\hline iii. & bare plotline & elaborative detail \\
\hline iv. & bare verbs & modified verbs \\
\hline $\mathrm{v}$. & subject elision & overt subject \\
\hline vi. & no repetitions & repetitions \\
\hline vii. & $\mathrm{V}(\mathrm{S})$ order & SV order \\
\hline viii & short verbal chains & longer chains \\
\hline$i x$. & parataxis & hypotaxis \\
\hline$x$. & asyndesis & syndesis \\
\hline
\end{tabular}

Discussion of Table 3 .

\section{i. Verbal forms}

The default adult plotline of perfective past verbs is extremely fast flowing. The non-past verbal forms decelerate by stretching events out in their progression (narrative present,, presentative present) or as states (presentative participles, participial compounds), or by invoking them (narrative imperative). In all these, the dynamic "movie show" is halted into a static "slide-show".

\section{ii. Lexical content (type)}

Fast flowing physical action on the adult plotlines is largely depicted in motion verbs. Perception verbs and saying verbs, on the other hand, slow down the pace, since cognition and dialogue do not actually move the physical plotline forward, but rather supply implicit evaluations, emotions, etc. Perceptions and speech are thus characteristic of thematic peaks, while motion leads up to the actional peaks. Between them, motion verbs, perception verbs, and speaking verbs make up a large proportion of the adult legends, swinging the rhythm to and fro.

Children narrate of motions, perceptions and speech too, of course, but use less verb types and tokens for them (2.3 above and sect. 3 below), so the general effect is less dynamic, with less variation between fast and slow.

\section{iii-vi. Lexical content (quantity)}

The fast adult plotline of bare, unmodified verbs may be decelerated by lexical elaboration in the form of post-verbal modification, subject specification (a form of repetition or redundancy), as well as lexical elaboration and repetiton in general. All these slow down the information flow of the dynamic, verbal plotline to a more static, nominal representation.

The children's basic plotline is the slow configuration of subject specification, post-verbal modification, and much repetition, though lexical detail is not abundant. 


\section{vii-x. Syntax}

The default adult plotline of short, paratactic, asyndetic $\mathrm{V}(\mathrm{S})$ chains is extremely fast. Longer chains, SV order, hypotaxis, and syndesis slow the pace down at peaks. In the children's style, however, SV, syndesis, and fuzzily bounded chains characterize the basic plotline as a slow, monotonous configuration.

In sum, the adults' basic configuration belongs to the fast type-- bare, unmodified verbs and compounds, most prominently motion verbs, packaged paratactically and asyndetically as separate events on a streamlined plotline. Stylistic variations in all these parameters make for a highly variable tempo, as the fast, densely packaged basic plotline alternates with slower information flow at peaks, where the narrator wants to linger for the accumulation of tension (Fleischman, 1990).

The children's narrative tends towards the slow configuration throughout: list-like chains of relatively long, syndetic, overt SV sequences of post-modified verbs dominate the children's texts, often in the narrative present. Stylistic variation is limited: there are almost no bare verbs, such as the lone 'came', on the one hand, nor any motion compounds on the other hand. This uniformity slows the pace down, especially when repetition sets in for repair purposes.

The slow rate of information flow in children's narratives may contrast with the actual pace of performance-- the latter may be very fast, out of sheer anxiety to get through successfully and uninterrupted. The sum effect of these two factors is of long winding narrating, contrasting with the rapid, varied dramatic effect of the adult style. All this is in apparent paradox to the actual genre structure, which is long and winding in the adult legends, short and compact in the children's folktales and anecdotes.

\section{Summary: the narrative layer}

The default adult narrative layer consists of paratactic, asyndetic, subjectless sequences of clause-initial verbs in the distant F-form. This tightly packed, fast verbal plotline is varied by tense switching, word order, overt subject, sequence length, repetitions, lexical connectives, etc. for perspective, connectivity, text segmentation, and pace control.

Children's narrative is predominantly paratactic and syndetic, with explicit SV in the narrative present and is connected by empty 'and then'; it is generally slower, flatter, less varied, and nearer the conversational register. Some older children, however, made effective use of textual connectives typical of folktales.

Now we proceed to a non-narrative layer of the text, direct speech.

\section{Direct Speech}

Direct speech is a known typological feature of preformed stories (Fleischman, 1990). It is indeed so predominant in the dramatic adult Negev texts, that some give the impression of a play rather than a narrative. This theatrical, evaluative, "dialogue-style" is very characteristic of the Bedouin legends--it is not nearly as frequent in sedentary Palestinian folktales (Henkin, 1996); nor is it very frequent in our children's style. Moreover, the packaging strategies and language of direct speech differ in the adults' and children's texts. 


\subsection{Packaging of speech segments}

Some prominent characteristics of adult speech packaging and keying are demonstrated in the following:

(25) I-găl l-ha: yā bint, anô warā-y nās. '(He) said to her, "Girl, I have people

2 gälar l-ih: ana minn-ak u-xuligr.

3 gäl il-ha: isma'iy.

4 gälar: āh.

Sgäl: ana āhid-kiy b-Allāh

6gälar: ana ma'-ak.

İgäl: 'ale-kiy Allāh illa arja'

sgälar: $m a-a k$ dilūl...?

g-gàl: ma'â-y.

10gäl: ya'ni gadd-ēs bijijib?

11 mamšar tala riyyām bijijib fi. yōm.

following".

(She) said to him, "I am part of you".

(He) said to her, "Listen".

(She) said, "Yes".

(He) said, "I swear to you by God..."

(She) said, "I am with you".

(He) said, "(By) God I'll return".

(She) said, "Do you have a riding camel?"

(He) said, "I do".

He (=she) said, "How much does it do?"

12 gălar: la'. fi alli mamšat sbū' bijjīb-ih fi. yōm (She) said, "No, there's one that does a week's ride in a day".' R53-58

The following are some salient characteristics of this performed play-style:

(i) Large bulks of speech, segmented to minimal units, e.g., $\underline{3}$ ["Listen"]; 4 ["Yes"]; lone vocatives; and partial repetition of question in one-word answer $(\underline{9})$;

(ii) densely packed saying verbs, usually subjectless and objectless ( $\underline{4}-\underline{10})$ serving also for asking, crying, pleading, etc. ( $\underline{8}, \underline{1} \underline{0}$, and see also 2.3);

(iii) non-specified speakers $(\underline{1-11})$; non-agreement of speech verb to speaker $\left(\frac{10}{)}\right)$; unkeyed speech $(\underline{11})$.

These features create two apparently contradictory effects around dialogue sections, typically at thematic peaks: on the one hand a distinct acceleration and an urgent, swirling, effect are felt; on the other hand, by chopping up a given piece of dialogue content and constantly repeating the verb of saying, the information flow is considerably down, thus keeping the suspense around the peaks, and giving the listener more thinking time. The intensive repetition of the saying verb also has rhetorical, alliterative effects, especially when no change of speaker is involved and the speech of one character is broken up by a saying verb, as in $(26 \underline{\underline{2}}-\underline{3})$ and $(30 \underline{\underline{3-4}})$ :

(26) Igäl: faraštily al-manām? 2gälat: faraš $-i h$.

3gälar: asma

4gāl: āh.
'(He) said, "Have you made the bed?"

(She) said, "I have made it".

(She) said, "Listen".

(He) said, "Yes".'
R45-48

The rhythm is very jerked in such cases, especially when the disrupted speech segments are also short, and when the elliptic subject of gāl is ambiguous. 
This is in fact very often the case, as the narrators do not stick to the pattern A speaks, then B answers, then A speaks again. 22

Children packaged speech very differently: they kept fairly uniform speech segments, neither "chopping up" speech nor intentionally adding speech verbs within one character's speech. They did sometimes omit explicit subjects across subject change, causing ambiguity, in a way that would be ungrammatical in adult style:

(27) ja šahhāad,

(28) ja Wusairūn,

gâl.
'(There) came a beggar,

said (one of the children), “...” JZ2

W. came,

said (the beggar), “.... “' JZ4

The ellipsis does not seem to be an intentional technique for dramatizing or accelerating, but rather the result of hurried, disorganized speech and unawareness of the problem of speaker tracking. More often, however, children take pains to identify speakers, and may overmark identities repetitively. Time gaining may be a factor in this kind of repetition. The beginning of (29) is an example:

(29) Ikull ma tgūl al-honno, tagūl: yā banār, inna b'adna.

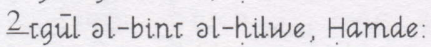
yà banāt, inna biadna.,

3bigūlan il-ha: la badri, asma'id-dīk fi nuss ol-arab.

4yā banāt, inna 'ab'adna.

$5 a r$ 'a $n$-nās ibyarhanū.

6yā banāt, inna 'ab'adna.

I'ar'a $n$-nās biwallo 'u fi l-babūr
Every time she says to them, she says, "Girls, we've strayed", (she) says, the pretty girl, H., "Girls, we've strayed", (they) say to her, "No, it's early, listen to the rooster among the folk".

"Girls, we have strayed".

"There's the people grinding".

"Girls, we have strayed".

'There's the folks lighting an oven". JA5-9

The above conversation, the longest in the children's corpus, is cited in its entirety to show the "intermediate" character of the older children's direct speech style. Unlike the younger children, this 12-year-old used the mature narrational technique of unkeyed speech (29-ㅡㄴ). Also, she repeated certain speech segments for textual connectivity in the favoured threefold pattern, in adjacent comment-response pairs $(292,4,6: 3,5,7)$. This technique, which we also saw with presentatives and repetitions in the narrative layer, is typical of the

22 R7-9 is one example out of many for speaker ambiguity, where none of the speakers or listeners are specified:

gall l-ih: [......] '(He A) said to him(B), ["......."].

găl. l-ah: [tayyib]. (HeB) said to him(A), ["OK"].

găal: [birjî lamin-na njĭf-aš-šigg ..] (HeB) said, ["(You) shall come when we're in

the men's circle.."I'

Moreover, the form of the verb is not a reliable criterion for speaker tracking, as fossilized gāa '(he) said' frequently denotes a general impersonal subject, to be translated as 'someone said', 'people said', even 'she said', e.g., R24, 57. 
folktale: folktales are full of formulaic utterances, often rhymed, as cohesive refrains in parallel episodes. The open-ended, non-recursive, winding legend genre, on the other hand, has little use for these linking means.

Another examnle unf .Joar' itartaf' repectition in speech' is in a 13-year-old's little story about cleanliness, cp. (5)-- the scruffy little girl who goes from one to the other of her animal playmates, asking each one to play with her, receives the same negative reply from each, in the same words.

There are also cases of speech repeated at a distance, for global linking. For example, in a 13-year-old's version of the widespread tale about the three kids and the wolf (cp. Muhawi \& Kanaana, 1988, Tale 38), the mother-goat's 4-lined rhymed "password" to have the kids open the door is repeated four times. Finally, in the best-structured folktale of this corpus, already cited in several examples, three brothers offer olives from their trees to an old man, who then rewards them, then punishes two when they become selfish. Parallel speeches for, and by, all three recur throughout.

The older children, then, seem sensitive to the textual functions of repetitive speech in folktale narrating, although their repetitions within the mimetic mode also indicate stumbling, backtracking, and overspecifying in a premature fashion.

\subsection{Speech grammar and lexicon}

Some inevitable grammatical characteristics of speech are 1 st and 2 nd persons, interrogatives, imperatives, modals, and conditionals. At the level of discourse grammar, spoken language tends towards analytic structure, SV order, extrapositions, parataxis, syndesis, ellipsis, vague lexemes, repetitions, fillers, and more (Brown \& Yule, 1983; Fleischman, 1990). Some of these features were found in section 2 to be typical of the children's narrative, as distinct from the adults'. The question then rises whether the speech and narrative modes are less differentiated in the children's texts than in the adults' respective styles. To test this, equal segments of adults' and children's narrative and speech layers should be analyzed for colloquial grammar and lexicon. I have so far analyzed a preliminary sample. The results, in total raw figures, are shown in Table 4: 
TABLE 4: ADULTS' AND CHILDREN'S DIFFERENTIALS IN NARRATIVE AND SPEECH 23

\begin{tabular}{|c|c|c||c|c|}
\hline & \multicolumn{2}{|c||}{ ADULTS (A3-11) } & \multicolumn{2}{c|}{ CHILDREN (JA24-31) } \\
\hline DIFFERENTIAL & NAR. & SPEECH & NAR. & SPEECH \\
\hline & & & & \\
\hline u-syndesis: asyndesis & $1: 8$ & $6: 3$ & $6: 3$ & no conjoined clauses \\
overt: elided sbj. pro. & $1: 8$ & $3: 3$ & $5: 5$ & $3: 1$ \\
\hline SV: VS & $0: 3$ & $5: 0$ & $4: 1$ & $3: 0$ \\
\hline extrapositioning & 0 & 2 & 0 & 1 \\
\hline
\end{tabular}

Although the sample is far too small to provide conclusive evidence, it does show an interesting constellation:

a) the child's narrative column is proportionally almost identical to the adult's speech column;

b) In the adult sample the ratios reverse or differ significantly from narrative to speech: while in narrative syndesis was a marked packaging means (cp. 2.6.2), in speech it is asyndesis that is marked for fusing actions, e.g., min yiš $\bar{u} f$ yirūh ydawwir ...? R5 'Who will look out, go out and look for....?' Likewise, we saw VS order in adult narrative to be the unmarked order (2.2), whereas in speech it serves for focalizing an action, e.g., the answer to "Why didn't you bring the birds?" is axad-hen wehed min häda A22 lit. "(There has) taken them someone just now", i.e., 'Somebody just took them'. Explicit subject marking also rose a lot in adults' speech in comparison to their narrative. In the children's sample, on the other hand, there is no reversal of markedness: the figures change somewhat in the direction expected, i.e., direct speech tends more to syndesis, subject specifying, SV, and extrapositioning; but the changes are nowhere near as drastic as in the adult sample.

It seems, then, that the grammatical differences between adult diegetic (narrative) and mimetic (speech) modes are much greater than those between the children's respective modes. In other words, the adults use distinct styles in the diegetic and mimetic modes, while the children's style is less differentiated, and resembles the adults' mimetic style.

Direct speech within the adult narratives also shows an extremely large measure of lexical material specific to the mimetic mode, as seen in (30)-emotive, personalized expression in the form of vocatives $(\underline{1}, \underline{2}, \underline{3})$, invocations ( 1 5 ), blessings, interjections, and colloquial expressions in general:

23 Excluding grammaticalized elements, such as obligatory VS order after the subordinating $m \bar{a}$, subjectless imperatives, and dislocation in the negated copula $\mathrm{NP}_{1} m u-h \bar{u} \mathrm{NP}_{2} \mathrm{NP}_{1}$ isn't (lit. 'he') $\mathrm{NP}_{2}$ '. 
(30) Igāl: y $\bar{a}$ sātir, yā yumma, 'alām-kiy? '(He) said,"O Protector, O Mother, what's wrong with you?"

2gälat: $w$-allah yā walad-i....

(She) said, "By God, O my son..."

3̈gäl l-ih: yā sātr-i,

4 găl: $w$-allāhi.

5gälat: $w$-allahi...

(He) said to him (=her), "O my Protector,"

(He) said, "By God...."

(She) said, "By God..."' R543-4

The children, on the other hand, seemed only to make use of obligatory mimetic lexemes, such as vocatives, and these too were not frequent. The only invocation I found was a standardized formula, part of a daring game ritual: Allah yil'an abü-ha lli... JA29, 33 'God curse her father who(ever fails to respond to the daring challenge)'.

Both grammatically and lexically, then, we find that adults, but not children, seem to intentionally "colloquialize" their mimetic mode with respect to the surrounding narrative. Such artistic "speech modulating" efforts characterize performed colloquial. Certain lexemes associated with speech, such as wallab "by God...., a pragrmatic marker of determination, hesitation, etc., serve to key speech within narrative, as do grammatical colloquial features. This extra colloquializing of the adult mimetic mode serves several purposes: primarily, of course, it disambiguates by keying speech from within (as distinct from external keying by means of speech verbs). Moreover, a clear, even overplayed, stylistic differentiation of the mimetic and diegetic modes shows up the mature narrator's proficiency in manipulating styles; an additional immediate effect is communicative-- to draw the listener in through personalized language.

The children do not yet display this stylistic flexibility. They do not seem to colloquialize their direct speech, grammatically or lexically, more than it already is. On the contrary, the children's mimetic mode, like the children's openings we have seen (1.1), may contain literarisms in formulas and memorized quotes from the semi-literary folklore. A typical example is the rhymed refrain from the

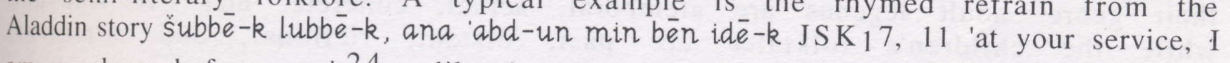
am a slave before you'; 24 likewise the formulized inquiry on encountering an unknown: anti jins walla 'ins? JA14 'are you a kind (of non-human) 25 or a human?' and the reply ana jins (sic.) min xiyär ol-musilmin 'I am a kind of the choicest Muslims'. We find literary phrases such as a'la $n-n \bar{a} s$ JSK $_{1} 11$ 'the loftiest of people', and literary syntax, glossed to colloquial, in 'urlubu mā.man...ès ma widd-kū JSK 17 'Ask for whatever (literary), whoever, whatever (colloquial) you want'. Apart from such literary influence, the children's direct speech is similar to their narrative.

24 This highly opaque binomial is constructed with a rhyming, probably nonsensical, element for the classical labbay-ka 'at your service'. Literary morphology is retained here in 'abd-un 'a slave', elsewhere in Palestinian folktales in colloquial form 'abd-ak 'your slave'. (Muhawi, personal communication).

25 jins 'a kind' alternates in this formula with the original, more transparent, but apparently less frequent, jinn The present version, possibly a euphemism, has the additional advantage of perfect rhyme insjins. Noteanci 'you'FM., a literary form. The opacity of this formula for the narrator is obvious from the reply, where the wrong option is selected, the proper answer being 'I am a human ('ins) from tho 
Some remaining characteristics of speech not analyzed in this paper include local repetitions (lexical and syntactic) 26 and fillers such as the vague ši 'thing' and flān 'so and so'. These may be pragmatically functional in conveying the actors' or the narrator's frame of mind, which, as we saw, do not usually find expression in the narrative (2.3):
(31)
w-allah flān dibahaw-h
'By God, so and so, (they) killed him, killed him, killed him!'
$\mathrm{R}_{1} 32$

Naturally the speaker did not actually say flän, when referring to her murdered husband; flān is the narrator's choice of representing a specific proper name with a common vague one, thus reducing its textual importance, which may contrast with its importance to the speaker, as expressed by other means, such as extraposition, repetition, oaths, etc. These I leave to future research.

\section{Summary: direct speech}

Adults' direct speech is packaged into curt, "ping pong" style segments, often non-keyed or over-keyed; speech is highly colloquialized, emotive, and evaluative in its grammar and lexicon.

Children do not artistically colloquialize nor chop up speech segments, which apart from literarisms, resemble their narrative; older children use recurring speeches in a global binding function.

\section{Final summary}

The formulaic, genre-specific openings reflect the narrators conception of their genre: adult legends are atemporal, actual, concrete, and ever-relevant, while the children's folktales are past, distant, fictional, and somewhat literarized.

Beyond the opening, once the relevance status has been set, an opposing shift takes place: the adults basically narrate in past tense, while the children tend to relive the events in the present.

But the most prominent difference between the styles is of flexibility: adults had distinct performed, highly evaluative styles for the diegetic, the mimetic, and the commentative modes; for these three text layers the children used a relatively undifferentiated, "flat" style, resembling mostly the conversational register.

The adults' basic plotline is a rapid configuration of paratactic, asyndetic sequences of bare past V(S), e.g., 'Came. Took fright. Receded'. The multitude of perspectivizing, text segmenting, packaging, connective, and tempo control techniques included narrative present, narrative imperative, presentatives, motion verb compounds, word order and chain length alternations, overt subject marking, syndesis, hypotaxis, and repetitions. By deviating from the distinct

26 Typically, part of a yes/no question is repeated in the answer:
(a) sirr 'indi-kiy fi $\underline{i}$ irr?
gälar: fï bìr.
'Is a secret with you (as safe as) in a well?"
(She) said, "In a well".'
$\mathrm{R} 138$

(b) w-ana bass l-ayy rāiut al-bēt.

'And all I want for me is the housewife".

gäluw: rāiut al-ber l-ak

(They) said, "The housewife is_yours".' R 120 :

Cf. also $(18,26)$ above, and Bendavid (1971) on parallels in Biblical 
default structure of each text layer, these kept a dynamic balance between distant and concrete, background and foreground, dynamic and static, fast and slow, etc.

Children switched less forms, more mechanically: they drifted towards the concrete, slower pattern of syndetic overt SV, often in non-past, e.g., 'and then he comes, and then he chases her, and then she climbs on the roof'. They eliminated genre-specific characteristics of the Bedouin oral narrative, such as backstitching and narrative imperative"

Adults used large, frequent chunks of speech, packaged in extremely short units, often elliptic and non-keyed, with marked spoken and emotive performed features; this made their texts very play-like. Children did not "artistically colloquialize" perform, nor segment their speech. Apart from some folkloristic literary quotes, direct speech was similar to narrative in the children's texts.

All this supports the findings of crosscultural developmental research (e.g., Labov, 1972; Berman \& Slobin, 1994), that preadolescents' storytelling is flatter, more stereotyped, less evaluated than adults', with less attention to recipient design in orientation, global signification (preventing the "So what?" question), or communicative interaction. Children lack the dimension of evaluation that turns an impartial chronicle or report to a narrative (Fleischman, 1990).

Some of the older children, however, were competent in organizing their folktales globally, using text-cohesive rhetorical means typical of this genre, such as tense switching, repetitions, presentatives, and formulaic speech, in recurring, formulaic scenes. This possibly shows that these children, at this age, are more sensitive to global textual structure than to local rhetorical means of evaluation. Clearly, more work needs to be done on Bedouin adult and child stylistics. 


\section{REFERENCES}

Bamberg, M. \& V. Marchman (1994) Foreshadowing and wrapping up in narrative. In R. A. Berman \& D. I. Slobin (eds.), Relating events in narrative: A crosslinguistic developmental study. Hillsdale, NJ: Lawrence Erlbaum Associates, 555-590.

Bauer, L. (1926) Das palästinische Arabisch: Die Dialekte des Städters und des Fellachen, 4th ed. Leipzig: Hinrichs'sche Buchhandlung.

Behnstedt, P. \& M. Woidich (1988) Die ägyptisch-arabischen Dialekte, Vol 3. Texts. Wiesbaden: Dr. Ludwig Reichert.

Bendavid, A. (1971) lešon mikra u-lešon xaxamim [Biblical Hebrew and Mishnaic Hebrew ], Vol. 2. Grammar and style. Tel Aviv: Dvir.

Berman, R. A. (1996, July) Setting the narrative scene: How children begin to tell a story. Plenary Lecture presented at the conference of the International Association for the Study of Child Language, Istanbul.

Berman, R. A. (in press) Form and function in developing narrative abilities. In D. I. Slobin, J. G. Gerhardt, A. Kyratzis \& J. Guo (eds.), Social interaction, social context, and language. Hillsdale, NJ: Lawrence Erlbaum Associates.

Berman, R. A. \& D. I. Slobin (1994) Relating events in narrative: A crosslinguistic developmental study. Hillsdale, NJ: Lawrence Erlbaum Associates.

Blau, J. (1960) Syntax der palästinensischen Bauerndialekts von Bīr Zèr. Beiträge zur Sprach-und Kulturgeschichte des Orients, Heft 15, Walldorf-Hessen.

Brown, J. \& G.Yule (1983) Discourse analysis. Cambridge: Cambridge University Press.

Caubet, D. (1995) ža, élément narratif dans le récit familier en arabe marocain. In Dialectologia Arabica: A collection of articles in honour of the sixtieth birthday of Professor Heikki Palva. Studia Orientalia, edited by the Finnish Oriental Society, 75. Helsinki, 41-48.

Chvany, C. V. (1984) Backgrounded perfectives and plot-line imperfectives: Towards a theory of grounding in text. In M.S. Flier \& A. Timberlake (eds.), The scope of Slavic aspect. Columbus, OH: Slavica Publishers, 247-273.

Fleischman, S. (1989a) A linguistic perspective on the laisses similaires: orality and the pragmatics of narrative discourse. Romance Philology 43 (1).

Fleischman, S. (1989b). Temporal distance: A basic linguistic metaphor. Studies in Language 13: 1-50.

Fleischman, S. (1990) Tense and narrativity. Austin: University of Texas Press.

Gensler, O. (1976) Tense in 'Aäärma Arabic. Unpublished manuscript. University of California at Berkeley. 
Henkin, R. (1985). ma'arexer ha-po'al šel lahagey beduim ba-negev--zmanim veaspektim [The verbal system in Negev Bedouin dialects: Tense and aspect]. Unpublished doctoral dissertation, Tel-Aviv University, Israel.

Henkin, R. (1992) ktanim 'im harbe avar: le-šimušim yixudiiyim šel zman he-avar bilšon yeladim [Children with a prolific past: On some unusual uses of the past tense in child language]. Lešonenu 55 (4): 333-362.

Henkin, R. (1993). 'To be' (or not) in the Bedouin Arabic dialect of the Ahaywät (Sinai). Mediterranean Language Review 6-7, 1990-1993: 173-197.

Henkin, R. (1994a) yeš gam et ze: [There's also this: On existential and possessive constructions in modern colloquial Hebrew]. Hebrew Computational Linguistics 38: 41-54.

Henkin, R. (1994b) The narrative imperative in colloquial Arabic and in Russian. Journal of Semitic Studies 39(2): 245-283.

Henkin, R. (1996) Negev Bedouin vs. sedentary Palestinian narrative styles. Israel Oriental Studies 16: 169-191.

Herring, S. C. (1991) Functions of the verb in Tamil narration. Unpublished doctoral dissertation, University of California at Berkeley.

Holes, C. (1995) The structure and function of parallelism and repetition in spoken Arabic: a sociolinguistic study. Journal of Semitic Studies 40 (1): $57-81$.

Hopkins, S. (1990) The word gayr. In Stewart, F. H. Texts in Sinai Bedouin law. Part 2. Mediterranean Language and Culture Monograph Series, 5. Wiesbaden: Otto Harrassowitz, 297-300.

Labov, W. (1972) Language in the inner city: Studies in the Black English vernacular. Philadelphia: University of Pennsylvania Press.

Lüthi, M. (1982) The European folktale: Form and nature (J. D. Niles, (Trans.). Philadelphia: Institute for the Study of Human Issues.

Muhawi, I. \& S. Kanaana (1988) Speak, bird, speak again: Palestinian Arab folktales. Berkeley: University of California Press.

Palva, H. (1977) The descriptive imperative of narrative style in spoken Arabic. Folia Orientalia 18: 5-26.

Palva, H. (1991) The form jāk in Bedouin narrative style. Studia Orientalia, 67: 5564.

Palva, H. (1992) Artistic colloquial Arabic. Studia Orientalia, edited by the Finnish Oriental Society 69. Helsinki.

Piamenta, M. (1979) Islam in everyday speech. Leiden: E.J. Brill.

Rosenhouse, J. (1984) The Bedouin Arabic dialects: General problems and a close analysis of North Israel Bedouin dialects. Wieshaden. 
Sebastián, E. \& D. I Slobin (1994) Development of linguistic forms: Spanish. In R. A. Berman \& D. I. Slobin (eds.), Relating events in narrative: A crosslinguistic developmental study. Hillsdale, $\mathrm{NJ}$ : Lawrence Erlbaum Associates, 239-284.

Sowayan, S. A. (1992) The Arabian oral historical narrative: An ethnographic and linguistic analysis. Semitica Viva 6. Wiesbaden.

Warnant, L. (1966) Moi, j'étais le papa: L'imparfait préludique et quelques remarques relatives à la recherche grammaticale In Mélanges de grammaire française offerts à $M$. Maurice Grevisse pour le trentième anniversaire du Bon usage. Gembloux: Duculot, 343-366.

Wolfson, N. (1982) CHP: The conversational historical present in American English narrative. Topics in sociolinguistics, 1. Dordrecht: Foris Publication. 